\title{
Thoughts Unlocked by Technology-a Survey in Germany About Brain-Computer Interfaces
}

\author{
J. R. Schmid · O. Friedrich · S. Kessner • \\ R. J. Jox
}

Received: 26 April 2020 / Accepted: 2 June 2021 / Published online: 2 November 2021

(C) The Author(s) 2021

\begin{abstract}
A brain-computer interface (BCI) is a rapidly evolving neurotechnology connecting the human brain with a computer. In its classic form, brain activity is recorded and used to control external devices like protheses or wheelchairs. Thus, BCI users act with the power of their thoughts. While the initial development has focused on medical uses of BCIs, non-medical applications have recently been gaining more attention, for example in automobiles, airplanes, and the entertainment context. However, the attitudes of the general public towards BCIs have hardly been explored.
\end{abstract}

Supplementary Information The online version contains supplementary material available at https://doi. org/10.1007/s11569-021-00392-w.

J. R. Schmid $(\bowtie) \cdot$ S. Kessner

Institute of Ethics, History and Theory of Medicine,

Ludwig-Maximilian-University Munich, Lessingstraße 2, 80336 Munich, Germany

e-mail: jennifer.schmid@campus.lmu.de

S. Kessner

e-mail: steffinoerte@web.de

\section{O. Friedrich}

Faculty of Cultural and Social Sciences, Institute

of Philosophy, Distance University in Hagen,

Universitätsstraße 33, 58097 Hagen, Germany

e-mail: orsolya.friedrich@fernuni-hagen.de

R. J. Jox

Institut des Humanités en Médecine, Lausanne University Hospital (CHUV) and University of Lausanne, Avenue de Provence 82, 1107 Lausanne, Switzerland
Among the general population in Germany aged 18-65 years, a representative online survey with 20 items was conducted in summer $2018(n=1000)$ and analysed by descriptive statistics. The survey assessed: affinity for technology; previous knowledge and experience concerning BCIs; the attitude towards ethical, social and legal implications of BCI use and demographic information. Our results indicate that BCIs are a unique and puzzling way of human-machine interaction. The findings reveal a positive view and high level of trust in BCIs on the one hand but on the other hand a wide range of ethical and anthropological concerns. Agency and responsibility were clearly attributed to the BCI user. The participants' opinions were divided regarding the impact BCIs have on humankind. In summary, a high level of ambivalence regarding BCIs was found. We suggest better information of the public and the promotion of public deliberation about BCIs in order to ensure responsible development and application of this potentially disruptive technology.

Keywords Brain-computer interfaces · Neuroethics · Public survey $\cdot$ General public $\cdot$ Online survey $\cdot$ Empirical research

\section{Introduction}

A brain-computer interface (BCI) unlocks human intentions through the use of technology. It measures, processes and transfers brain activity signals into 
commands for external devices, enabling the person to perform certain tasks without the use of traditional neuromuscular output pathways, e.g. to move a computer cursor, prosthesis, robotic arm, wheelchair or other devices [1,2]. In medicine, the main goal of BCIs is to replace, restore or supplement impaired neuromuscular functions of patients [3]. BCIs might also be helpful for rehabilitation purposes after stroke [4-6]. There are, however, also various non-medical applications of BCIs, for example in the fields of entertainment and gaming, product design and education, often associated with the goal of enhancing ordinary human performance [7-13].

BCIs are not only a rapidly growing research area, but they also attract the interest of ethicists, legal scholars and the general public. So far, ethicists have mainly conducted theoretical discussions on risk-benefit ratio and safety concerns, personhood and stigma, agency, autonomy, responsibility, privacy and justice [14-17]. However, an empirical evaluation of moral concerns, fears and expectations of BCI users, or potential users, is scarce [14, 18]. Often, the user perspective is indirectly accessed via experts' opinions or presents merely an add-on to a technology study [17-23]. Here, a strong focus lies on questions of acceptance, usability and satisfaction with the aim to improve technological aspects [24-28].

\section{Previous Own Research}

In a previous scoping literature study, we thoroughly screened the existing body of social empirical studies on the experiences of BCI users in order to identify key themes and current research gaps [29]. This procedure showed that empirical studies among the general public and empirical evidence from a non-medical user perspective were conspicuously lacking, especially regarding social and ethical concerns beyond merely technical issues and questions of feasibility and acceptability [29]. Second, we conducted 24 qualitative interviews with non-medical participants of BCI studies, using qualitative content analysis aided by the software MAXQDA [30, 31]. All of them had experience with BCI use, e.g. as BCI gamers, developers of $\mathrm{BCI}$ technology or pilots steering a flight simulator via a BCI. Users' experiences and attitudes were highly heterogenous, depending on motivation, training duration and success in using the technology. Particularly striking was the ambivalence of attitudes, containing both enthusiasm and concerns.

Based on this previous research, our current paper presents one of the first empirical studies explicitly addressing the perspective of the general public on BCI technology. Our aim was to examine ethical, social and legal implications of BCIs as viewed by the general public. So far, academic ethics dominates the research field highlighting various ethical challenges associated with BCIs. Public engagement and empirical evidence supporting these mainly conceptual models are missing [14]. Hence, there is a strong need to involve the general, non-academic public focusing on actual and potential BCI use [9]. In this way, we aim to stimulate a broad discourse within society informing debates how neurotechnology—and BCIs in particular-should be developed and legally regulated in the future.

\section{Methods}

\section{Study Design}

Based on the scoping literature review [29] and the qualitative interview study [30] described above, we developed 20 items for a web-based public questionnaire survey, following a sequential, explorative mixedmethods approach [32-34]. The design of a web-based survey was chosen to elicit broadly representative data on attitudes towards BCIs among the general public.

\section{Pretesting}

Pretesting was realized among persons with no prior knowledge of BCIs using the think-aloud technique $[35,36]$. According to respondents' input, items were redrafted, positions were changed and a maximum number of 20 questions were selected. See the supplementary material for the constructs of the questionnaire including their respective items (Table 7) and the full version of the questionnaire (Table 8).

\section{Questionnaire}

The questionnaire explored (1) general affinity for technology (3 questions); (2) prior knowledge and experience with BCIs (2 questions); (3) desire to use BCIs (4 questions); (4) expectations regarding BCI use (3 questions); (5) potential ethical, social and 
legal implications of BCI use (8 questions) and (4) demographic information (4 questions). Items regarding affinity for technology were adopted from the questionnaire TA-EG (German: 'Fragebogen zur Erfassung der Technikaffinität als Umgang mit und Einstellung zu elektronischen Geräten') which is a widely established tool for measuring affinity to technical devices [37]. We consistently applied a 7-point Likert scale for almost all items $(1=\mathrm{I}$ completely disagree; 2 =I mostly disagree; 3 = I slightly disagree; $4=\mathrm{I}$ am neutral; 5=I slightly agree; $6=\mathrm{I}$ mostly agree; $7=I$ completely agree) $[38,39]$. Only for two items exploring prior BCI knowledge/experience ( $I$ know what a BCI is / I have already tested a BCI) a binary format (yes/no) was chosen due to accountability reasons.

After having been asked to self-report their affinity for technology and their prior BCI knowledge/ experience, participants were presented a two-minute introductory video about BCI technology and use. In this way, we aimed to create a common understanding of BCIs ensuring that all participants had the same idea in mind when answering the subsequent questions. In the first part of the video, BCI technology was explained in general by a BCI researcher, and it was shown how a paralyzed person successfully controlled a robotic arm via BCI. The second part showed how a woman was using a BCI to control a simple (non-military) drone in a non-medical context. By choosing different ways of application (medical vs. non-medical), we tried to avoid selection bias showing the diverse potential of this neurotechnology. The video sequences were drawn from two published videos, one created and published by BCI scientists and another one by science journalists from a renowned, public TV station; the permission of the authors was obtained before. Furthermore, the study obtained approval from the ethics committee at the local university (project number 18-600 UE).

Survey Distribution in the Population

A representative sample $(n=1000)$ of the adult population aged 18-65 years living in Germany was randomly selected out of a larger pool for a web-based survey via a commercial Internet panel provider. Participants came from all 16 geographical regions (states) of the country and received small-amount shopping vouchers for completing the questionnaire. The incentive should increase respondents' motivation while compensating for the time invested [14, 40, 41]. Participation was anonymous and voluntary. Answers to all questions were mandatory. Multiple participation was technically impossible. An average of six minutes was needed to complete the survey. It was conducted in summer 2018.

\section{Data Analysis}

The data from the 7-point Likert scale was trichotomized into three categories: (1) disagreement, (2) neutral judgement and (3) agreement. The clustering helped to ease the interpretation of the results without significant loss of information. Thus, the answers 'slightly/mostly/completely disagree' were summed up in the category 'disagreement'. The analogous procedure was applied to the category 'agreement'. Data analysis was performed with SPSS Statistics (version 25.0 for Windows). In accordance with the explorative nature of this study, we decided to use descriptive statistics for the interpretation of our results.

\section{Results}

\section{Respondents' Characteristics}

A thousand participants (500 female, 500 male) with an age range of 18 to 65 years $($ Mean $=43.60)$ and different levels of education and employment status took part in the study. Table 1 provides an overview of respondents' demographic characteristics.

\section{Affinity for Technology}

The respondents' affinity for technology was assessed using three global self-rating questions. About half of the participants $(50.5 \%)$ agreed with the statement that they are generally excited about technology, and only $22.9 \%$ disagreed with that statement (neutral: $26.6 \%$; see Table 2). A total of $73.1 \%$ expressed that they easily learn how an electronical device works (neutral: 17.3\%, disagreement: 9.6\%). Furthermore, $77.5 \%$ of the respondents had a positive view towards technology agreeing that electronical devices make daily life easier (neutral: 16.9\%, disagreement: 5.6\%). 
Table 1 Respondents' demographic characteristics $(n=1000)$

\begin{tabular}{|c|c|c|c|}
\hline \multicolumn{2}{|l|}{ Demographics } & \multicolumn{2}{|c|}{ Respondents } \\
\hline & & $n$ & $\%$ \\
\hline Gender & $\begin{array}{l}\text { Male } \\
\text { Female }\end{array}$ & $\begin{array}{l}500 \\
500\end{array}$ & $\begin{array}{l}50.0 \% \\
50.0 \%\end{array}$ \\
\hline Age (in years) & $\begin{array}{l}18-24 \\
25-34 \\
35-44 \\
45-54 \\
55-65\end{array}$ & $\begin{array}{l}110 \\
190 \\
190 \\
250 \\
260\end{array}$ & $\begin{array}{l}11.0 \% \\
19.0 \% \\
19.0 \% \\
25.0 \% \\
26.0 \%\end{array}$ \\
\hline Level of Education & $\begin{array}{l}\text { Lower secondary education } \\
\text { Upper secondary education } \\
\text { Post-secondary non-tertiary education } \\
\text { Bachelor or equivalent } \\
\text { Master or equivalent } \\
\text { Doctoral or equivalent } \\
\text { None of the mentioned above }\end{array}$ & $\begin{array}{l}141 \\
360 \\
269 \\
67 \\
136 \\
13 \\
14\end{array}$ & $\begin{array}{l}14.1 \% \\
36.0 \% \\
26.9 \% \\
6.7 \% \\
13.6 \% \\
1.3 \% \\
1.4 \%\end{array}$ \\
\hline Employment Status & $\begin{array}{l}\text { Pupil/student } \\
\text { Trainee } \\
\text { Unemployed/searching for employment } \\
\text { Part-time employee } \\
\text { Full-time employee } \\
\text { Freelancer } \\
\text { Pensioner/retired person } \\
\text { Housewife/house husband }\end{array}$ & $\begin{array}{l}74 \\
2 \\
65 \\
180 \\
416 \\
64 \\
125 \\
75\end{array}$ & $\begin{array}{l}7.4 \% \\
0.2 \% \\
6.5 \% \\
18.0 \% \\
41.6 \% \\
6.4 \% \\
12.5 \% \\
7.5 \%\end{array}$ \\
\hline
\end{tabular}

Lower secondary education = "Hauptschule", upper secondary education = "Mittelschule"/"Realschule", post-secondary non-tertiary education $=$ "Abitur"

\section{Previous Knowledge and Experience with BCIs}

In our sample, $31.2 \%$ indicated to know what a BCI is (disagreement: $68.8 \%$ ). Concerning actual user experience with this technology, $7.6 \%$ said that they have already tested a BCI.

\section{Desire to Use a BCI}

After having watched the introductory video, $57.0 \%$ of the respondents expressed the desire to use a BCI themselves, $18.0 \%$ had a neutral position and $25.0 \%$ did not express the desire to use it (see Table 3). If using a BCI required wearing a cap of electrodes on their head, $42.0 \%$ said that they would still want to use the technology, $20.2 \%$ were neutral and $37.8 \%$ would renounce using it for this reason. Another item explored the aesthetic aspect of BCIs: only $22.9 \%$ of the respondents agreed to be concerned about BCI use due to unfavorable appearance, while $20.7 \%$ were neutral on this issue and $56.4 \%$ were not concerned. Moreover, $45.1 \%$ of our sample would be willing to

Table 2 Results of the questionnaire concerning 'affinity for technology'

\begin{tabular}{|c|c|c|c|c|c|c|c|}
\hline \multirow[t]{2}{*}{ Statement } & $\begin{array}{l}\text { Completely } \\
\text { disagree }(\%)\end{array}$ & $\begin{array}{l}\text { Mostly } \\
\text { disagree } \\
(\%)\end{array}$ & $\begin{array}{l}\text { Slightly } \\
\text { disagree } \\
(\%)\end{array}$ & Neutral (\%) & $\begin{array}{l}\text { Slightly } \\
\text { agree } \\
(\%)\end{array}$ & $\begin{array}{l}\text { Mostly } \\
\text { agree } \\
(\%)\end{array}$ & $\begin{array}{l}\text { Completely } \\
\text { agree }(\%)\end{array}$ \\
\hline & \multicolumn{3}{|l|}{ Agreement } & Neutral & \multicolumn{3}{|c|}{ Disagreement } \\
\hline $\begin{array}{l}\text { I'm excited when a new electronical device } \\
\text { comes on the market }\end{array}$ & 4.7 & 6.6 & 11.6 & 26.6 & 21.3 & 17.3 & 11.9 \\
\hline $\begin{array}{l}\text { It's easy for me to learn how an electronical } \\
\text { device works }\end{array}$ & 1.4 & 3.4 & 4.8 & 17.3 & 24.0 & 25.3 & 23.8 \\
\hline Electronical devices make daily life easier & 0.6 & 1.0 & 4.0 & 16.9 & 27.3 & 26.0 & 24.2 \\
\hline
\end{tabular}


Table 3 Results of the questionnaire concerning 'desire to use a BCI'

\begin{tabular}{|c|c|c|c|c|c|c|c|}
\hline \multirow[t]{2}{*}{ Statement } & $\begin{array}{l}\text { Completely } \\
\text { Disagree } \\
(\%)\end{array}$ & $\begin{array}{l}\text { Mostly } \\
\text { Disagree } \\
(\%)\end{array}$ & $\begin{array}{l}\text { Slightly } \\
\text { Disagree } \\
(\%)\end{array}$ & Neutral $(\%)$ & $\begin{array}{l}\text { Slightly } \\
\text { Agree } \\
(\%)\end{array}$ & $\begin{array}{l}\text { Mostly } \\
\text { Agree } \\
(\%)\end{array}$ & \multirow[t]{2}{*}{$\begin{array}{l}\text { Completely } \\
\text { Agree }(\%)\end{array}$} \\
\hline & \multicolumn{3}{|c|}{ Disagreement } & Neutral & \multicolumn{2}{|c|}{ Agreement } & \\
\hline I would like to use a BCI myself & 11.1 & 5.7 & 8.2 & 18.0 & 18.6 & 14.3 & 24.1 \\
\hline $\begin{array}{l}\text { I wouldn't use a BCI, if I had to wear a cap } \\
\text { with electrodes }\end{array}$ & 15.9 & 11.8 & 14.3 & 20.2 & 12.8 & 10.5 & 14.5 \\
\hline $\begin{array}{l}\text { I would be concerned about BCI use because } \\
\text { it looks unfavorable }\end{array}$ & 27.7 & 14.8 & 13.9 & 20.7 & 10.7 & 5.0 & 7.2 \\
\hline $\begin{array}{l}\text { I would be ready to practice four weeks on a } \\
\text { daily basis to use a BCI }\end{array}$ & 13.2 & 7.5 & 12.1 & 22.1 & 19.6 & 9.8 & 15.7 \\
\hline
\end{tabular}

practice four weeks on a daily basis in order to become able to use a BCI (22.1\% neutral, $32.8 \%$ disagree).

\section{Expectations}

A key factor concerning the acceptance of new technologies is the fulfilment of users' expectations [42, 43]. Here, our findings reveal a strong wish for regulation. A total of $44.6 \%$ of the respondents were in favor of a BCI license (26.7\% were neutral, $28.7 \%$ disagreed; see Table 4). Even higher rates of agreement were achieved when asked whether a legal regulation of BCIs would be required (56.3\% agreement, $25.8 \%$ neutral, $17.9 \%$ disagreement). Furthermore, we asked participants about their trust in scientists concerning a responsible future BCI development: $46.5 \%$ expressed having trust in researchers (neutral: $29.0 \%$, disagreement: $24.5 \%$ ).

\section{Anthropological Implications}

In this paper, the term 'anthropological' refers to general questions of humankind in the field of human-machine relationships such as human actions, responsibility, ontological questions and the concept of personhood. A proportion of $69.1 \%$ of the respondents agreed that a BCI-modulated action is still a human action (neutral: 22.6\%; disagreement: $8.3 \%$ ). Furthermore, $76.1 \%$ of the participants agreed that the responsibility remains with the user (neutral: 18.1\%, disagreement: 5.8\%; see Table 5). However, the views were more divided with regard to the ontological status: $38.4 \%$ of the participants regarded BCI users as a mixture between man and machine, and the same percentage denied this view $(23.2 \%$ were neutral). Moreover, $43.4 \%$ of the respondents agreed with the statement that BCIs change our general concept of personhood, while $30.9 \%$ denied this, and $25.7 \%$ remained neutral.

\section{Fears}

More than half of the participants (55.3\%) agreed that high and unrealistic expectations associated with BCI use could lead to disappointment, $30.7 \%$ were neutral, and $14.0 \%$ were not concerned about this issue (see Table 6). Another $56.1 \%$ of our sample expressed the wish that BCI users should not be able to gain unfair advantages like faster reaction times (neutral: $29.7 \%$, disagreement: $14.2 \%$ ). In addition, $46.8 \%$ agreed to be

Table 4 Results of the questionnaire concerning 'expectations towards BCI use'

\begin{tabular}{|c|c|c|c|c|c|c|c|}
\hline \multirow[t]{2}{*}{ Statement } & $\begin{array}{l}\text { Completely } \\
\text { Disagree } \\
(\%)\end{array}$ & $\begin{array}{l}\text { Mostly } \\
\text { Disagree } \\
(\%)\end{array}$ & $\begin{array}{l}\text { Slightly } \\
\text { Disagree } \\
(\%)\end{array}$ & Neutral (\%) & $\begin{array}{l}\text { Slightly } \\
\text { Agree } \\
(\%)\end{array}$ & $\begin{array}{l}\text { Mostly } \\
\text { Agree } \\
(\%)\end{array}$ & \multirow[t]{2}{*}{$\begin{array}{l}\text { Completely } \\
\text { Agree (\%) }\end{array}$} \\
\hline & \multicolumn{3}{|l|}{ Disagreement } & Neutral & \multicolumn{2}{|c|}{ Agreement } & \\
\hline You should need a license for BCI use & 12.7 & 6.6 & 9.4 & 26.7 & 16.2 & 12.6 & 15.8 \\
\hline The use of BCIs should be regulated by law & 5.4 & 4.5 & 8.0 & 25.8 & 19.8 & 15.7 & 20.8 \\
\hline $\begin{array}{l}\text { I trust scientists that they develop BCIs in a } \\
\text { responsible way }\end{array}$ & 7.8 & 5.6 & 11.1 & 29.0 & 22.1 & 11.8 & 12.6 \\
\hline
\end{tabular}


Table 5 Results of the questionnaire concerning 'anthropological implications'

\begin{tabular}{|c|c|c|c|c|c|c|c|}
\hline \multirow[t]{2}{*}{ Statement } & $\begin{array}{l}\text { Completely } \\
\text { Disagree } \\
(\%)\end{array}$ & $\begin{array}{l}\text { Mostly } \\
\text { Disagree } \\
(\%)\end{array}$ & $\begin{array}{l}\text { Slightly } \\
\text { Disagree } \\
(\%)\end{array}$ & Neutral (\%) & $\begin{array}{l}\text { Slightly } \\
\text { Agree } \\
(\%)\end{array}$ & $\begin{array}{l}\text { Mostly } \\
\text { Agree } \\
(\%)\end{array}$ & \multirow[t]{2}{*}{$\begin{array}{l}\text { Completely } \\
\text { Agree }(\%)\end{array}$} \\
\hline & \multicolumn{3}{|c|}{ Disagreement } & Neutral & \multicolumn{2}{|c|}{ Agreement } & \\
\hline $\begin{array}{l}\text { A BCI-modulated action is still a human } \\
\text { action }\end{array}$ & 2.4 & 1.6 & 4.3 & 22.6 & 25.3 & 20.0 & 23.8 \\
\hline $\begin{array}{l}\text { The user is responsible for BCI-modulated } \\
\text { actions }\end{array}$ & 1.1 & 1.0 & 3.7 & 18.1 & 22.0 & 21.1 & 33.0 \\
\hline $\begin{array}{l}\text { BCI users are a mixture between man and } \\
\text { machine }\end{array}$ & 15.0 & 11.2 & 12.2 & 23.2 & 18.1 & 9.6 & 10.7 \\
\hline $\begin{array}{l}\text { BCIs change the understanding of person- } \\
\text { hood }\end{array}$ & 9.5 & 7.4 & 14.0 & 25.7 & 18.9 & 13.5 & 11.0 \\
\hline
\end{tabular}

afraid of mindreading through BCIs (neutral: 20.1\%, disagreement: $33.1 \%$ ). With $64.7 \%$, the majority of our sample agreed to be worried about BCI misuse; only $16.2 \%$ negated this statement, and $19.1 \%$ took a neutral position.

\section{Discussion}

We presented the results of one of the first empirical studies investigating population attitudes towards BCIs in a large sample of German citizens. This potentially disruptive technology connects the human brain with a computer, raising various ethical, social and legal implications that need to be discussed. Our study was based on an explorative design deriving its items from previously conducted qualitative research, including a scoping review of the literature and an interview study among non-medical BCI users. Our sample is representative of the German population in the age group between 18 and 65 years.
The findings reveal a relatively high technological affinity and a marked desire to use BCI technology, while only very few had already practical contact with BCI technology. About half of the participants would be willing to practice four weeks on a daily basis to achieve high performance. For a majority of respondents, the uncomfortable and aesthetically disturbing use of an EEG cap would not deter them from using a BCI. These results stand in contrast to the opinion of actual users from the interview study we had conducted before [30]. Here, the majority of participants would not be willing to practice on a regular basis, as long as there is no medical need. Also, the EEG cap and time-consuming procedure of EEG application were experienced as uncomfortable by the interviewees [30]. This finding is in accordance with the general trend in consumer neurotechnology towards smaller, aesthetically more attractive electrodes [44]. This discordance between potential users and actual users with practical experience may emphasize the difficulty to imagine how it is like to use a BCI.

Table 6 Results of the questionnaire concerning 'fears towards BCI technology'

\begin{tabular}{|c|c|c|c|c|c|c|c|}
\hline \multirow[t]{2}{*}{ Statement } & $\begin{array}{l}\text { Completely } \\
\text { Disagree } \\
(\%)\end{array}$ & $\begin{array}{l}\text { Mostly } \\
\text { Disagree } \\
(\%)\end{array}$ & $\begin{array}{l}\text { Slightly } \\
\text { Disagree } \\
(\%)\end{array}$ & Neutral (\%) & $\begin{array}{l}\text { Slightly } \\
\text { Agree } \\
(\%)\end{array}$ & $\begin{array}{l}\text { Mostly } \\
\text { Agree } \\
(\%)\end{array}$ & \multirow[t]{2}{*}{$\begin{array}{l}\text { Completely } \\
\text { Agree }(\%)\end{array}$} \\
\hline & \multicolumn{3}{|c|}{ Disagreement } & Neutral & \multicolumn{2}{|c|}{ Agreement } & \\
\hline $\begin{array}{l}\text { BCI users with high expectations could get } \\
\text { disappointed }\end{array}$ & 2.7 & 2.8 & 8.5 & 30.7 & 26.0 & 14.7 & 14.6 \\
\hline $\begin{array}{l}\text { BCI users shouldn't be able to gain unfair } \\
\text { advantages (e.g. faster reaction times) }\end{array}$ & 3.3 & 4.1 & 6.8 & 29.7 & 18.3 & 15.0 & 22.8 \\
\hline $\begin{array}{l}\text { I'm afraid that my thoughts could be read by } \\
\text { a BCI }\end{array}$ & 13.3 & 7.3 & 12.5 & 20.1 & 18.9 & 11.9 & 16.0 \\
\hline I'm afraid of BCI misuse & 4.8 & 3.4 & 8.0 & 19.1 & 22.9 & 15.6 & 26.2 \\
\hline
\end{tabular}


Despite the generally positive outlook on BCI technology, the respondents of our survey were far less concordant with regard to ethical, legal and social implications of BCIs. The rather heterogeneous answers may reflect uncertainty, ambivalence and the need for more reflection and debate. The most strongly shared worries seem to concern misuse, unfairness, mindreading and changes of personhood.

These parallel perspectives of both enthusiasm and worries are also evident in the literature where both seem to balance each other [14, 43, 44]. In our sample, it was particularly striking that the public displayed a high level of trust in scientists but still largely acknowledged the need for legal regulation and mandatory BCI licensing. This need for normative guidance is also shared by most BCI scientists and developers themselves, as the Asilomar survey showed ten years ago [17]. Such normative guidance in the form of international soft law on BCIs and neurotechnology is urgently lacking [17]. Only some researchers and international organizations have started to reflect on how such a regulation may look like $[45,46]$.

In this context, the enormous influence of mass media becomes evident. Many scientific articles have recently discussed the need for more regulation of neurotechnologies, painting a rather threatening picture of neurotechnology developments [47, 48]. However, a recently conducted media review shows quite the opposite [49]. The authors report that mass media portrays BCI technology in an overly positive and enthusiastic manner, including little negative or critical aspects and almost lacking any ethical discussion. Hence, a variety of media coverage towards BCIs exist which might highly influence the public evaluation of this technology.

It has been discussed that BCIs represent a unique way of fusion of man and machine [3, 50, 51]. However, our findings show no heightened concerns of the public related to this fusion. Two-thirds of the respondents agreed that a BCI-mediated action is still a human action. Furthermore, still one-third of the participants did not see a change in personhood; a quarter was neutral. These findings stand in contrast to clinical data. Patients raised serious concerns about the creation of self-transcending human-machine hybrids and reported feelings of loss of control and a rupture of their identity [43, 44, 52]. Furthermore, a study with stroke patients and persons suffering from amyotrophic lateral sclerosis (ALS) formulated concerns about BCIs creating techno-cerebral subjects [53]. One potential explanation for our survey results is that the kinds of BCIs that are tested today mainly relate to motor behavior, but do not directly interact with more intimate elements of a person, such as their emotions, their moral values and religious beliefs. Should BCIs one day be able to measure, influence and interact with these mental properties, e.g. based on recognition of anger, fear or happiness, this might indeed have more pronounced effects on personhood or personality [14]. First clinical trials for targeting psychiatric conditions with BCIs (closed-loop) have already been conducted [54]. Furthermore, increasing use of artificial intelligence and deep learning algorithms in BCIs as well as the development and wider use of passive BCIs might impact on the questions of personhood, agency and responsibility related to BCImediated actions $[55,56]$.

\section{Study Limitations}

Our study has methodological limitations. We chose a 7-point Likert scale, which is highly recommended in terms of reliability and validity [38, 39]. Despite this, however, a high number of items showed neutral judgements (4 on the 7-point Likert scale) in the range of $20-30 \%$, indicating that participants were uncertain or did not yet have fully developed opinions towards BCIs. As mentioned before, BCI technology is currently quite unknown in the general public [17]. Our finding that an astonishing third of respondents reported to know what a BCI is should be interpreted with caution: since these data were obtained before the instructional video explained BCIs, we cannot rule out that some respondents may have confounded BCIs with other technologies.

The overall positive evaluation of BCI technology might have been biased by the video, which portrayed BCIs in a rather positive way, yet it also mentioned various obstacles to BCI use (e.g. amount of training, cognitive exhaustion). A culturally specific factor impacting attitudes towards BCI might be social desirability since the German society has a generally positive perspective on new technologies. Germany is fond of its traditionally strong engineering, neuroscience and neurotechnology achievements, but also its neuro-ethics activities [57], and books on 
neuroscience and neurotechnology have been bestsellers in recent years [58-60].

Furthermore, the survey does not allow to differentiate between evaluations of responsibility or agency depending on the type of BCI used (e.g. active or passive $\mathrm{BCI}$ ). Our study focused on active BCIs where voluntary brain activity is recorded and processed so that the person can deliberately communicate or control devices. However, compared to closed-loop applications like deep brain stimulation or cochlear implants, active BCIs are currently rarely used on a regular basis [42].

\section{Conclusions and Future Implications}

This study was carried out to stimulate discourse about non-medical uses of BCIs including its ethical, social and legal implications. Our results generally support the development of BCI technology, but strongly urge the reflection, deliberation and documentation of ethical, anthropological and social concerns. Ethical guidance and legal regulation by adequate instances seem to be prerequisites for the wide-spread and lasting acceptance and uptake of $\mathrm{BCI}$ technology in the general public. We are facing a new era of converging IT and neurotechnologies whose manifold ethical, legal and social questions have not been answered yet [14, 61, 62]: Who is responsible for BCI-mediated actions and how can we reliably attribute responsibility and liability? How do these technologies alter the human brain, human identity and human societies? How can misuses be prevented and data security be guaranteed? These are just a few of the salient and unanswered questions.

Our sample strongly supported individuals' responsibility for BCI-mediated actions and the underlying view that BCI actions are still human actions. As BCI users themselves seem to have a tendency to rather deny their responsibility, at least for unsuccessful or harmful actions [30], it seems important to develop coherent rules for the ascription of individual agency and responsibility in the context of BCI use.

BCI technology is still in its early stages of development [1,2]. EEG application is prone to errors and highly dependent of individual factors such as anatomical structure. In addition, about $10 \%$ of users are unable to use a BCI successfully, a phenomenon often called BCI illiteracy [63-66]. In the years to come, the increasing integration of artificial intelligence and deep learning into BCIs may eventually blur the line between active and passive BCI technology, thus obfuscating the attribution of responsibility $[67,68]$.

Only a well-informed public can evaluate this development in a reliable and responsible way. Empirical studies such as this one can enrich normative analyses and regulatory considerations by identifying concrete concerns about use or options for action for decision-makers. Our results can trigger and inform a broader discussion among citizens and policymakers, with the idea to support a responsible and sustainable development, dissemination and use of BCIs. Additional studies in the form of representative surveys in other regions and populations, but also citizen conferences and comprehensive technology assessment, are necessary to guide this future development.

Funding Open Access funding enabled and organized by Projekt DEAL. This paper has been written in the interdisciplinary research project INTERFACES funded by the Federal Ministry of Education and Research (BMBF) in Germany and ERA-Net Neuron in the European Research Area Network for Neuroscience Research. Moreover, J. R. Schmid was supported by a Hanns Seidel Foundation scholarship.

\section{Declarations}

Competing Interests The authors declare no competing interests.

Open Access This article is licensed under a Creative Commons Attribution 4.0 International License, which permits use, sharing, adaptation, distribution and reproduction in any medium or format, as long as you give appropriate credit to the original author(s) and the source, provide a link to the Creative Commons licence, and indicate if changes were made. The images or other third party material in this article are included in the article's Creative Commons licence, unless indicated otherwise in a credit line to the material. If material is not included in the article's Creative Commons licence and your intended use is not permitted by statutory regulation or exceeds the permitted use, you will need to obtain permission directly from the copyright holder. To view a copy of this licence, visit http://creativecommons.org/licenses/by/4.0/. 


\section{References}

1. Shih JJ, Krusienski DJ, Wolpaw JR (2012) Braincomputer interfaces in medicine. In: Mayo Clinic Proceedings 87(3):268-279

2. Wolpaw JR, Birbaumer N, McFarland DJ, Pfurtscheller G, Vaughan TM (2002) Brain-computer interfaces for communication and control. Clin Neurophysiol 113(6):767-791

3. Graimann B, Allison B, Pfurtscheller G (2010) Braincomputer interfaces: A gentle introduction. In: Graimann B, Pfurtscheller G, Allison B (eds) Brain-computer interfaces: Revolutionizing human-computer interaction. Springer, Berlin and Heidelberg, pp 1-27. https://doi.org/ 10.1007/978-3-642-02091-9_1

4. Chaudhary U, Birbaumer N, Ramos-Murguialday A (2016) Brain-computer interfaces in the completely locked-in state and chronic stroke. Progress in Brain Research 228, pp 131-161

5. Buch E, Weber C, Cohen LG, Braun C, Dimyan MA, Ard T, Mellinger J, Caria A, Soekadar S, Fourkas A (2008) Think to move: A neuromagnetic brain-computer interface (BCI) system for chronic stroke. Stroke 39(3):910-917

6. Morone G, Pisotta I, Pichiorri F, Kleih S, Paolucci S, Molinari M, Cincotti F, Kübler A, Mattia D (2015) Proof of principle of a brain-computer interface approach to support poststroke arm rehabilitation in hospitalized patients: Design, acceptability, and usability. Arch Phys Med Rehabil 96(3):S71-S78

7. Blankertz B, Tangermann M, Vidaurre C, Fazli S, Sannelli C, Haufe S, Maeder C, Ramsey LE, Sturm I, Curio G (2010) The Berlin brain-computer interface: Non-medical uses of BCI technology. Front Neurosci 4(198):1-17

8. Bos DP-O, Reuderink B, van de Laar B, Gürkök H, Mühl C, Poel M, Nijholt A, Heylen D (2010) Brain-computer interfacing and games. In: Tan DS, Nieholt A (eds) Braincomputer interfaces. Applying our minds to humancomputer interaction. Springer, London, pp 149-178

9. Van Erp J, Lotte F, Tangermann M (2012) Braincomputer interfaces: Beyond medical applications. Computer 45(4):26-34

10. Verkijika SF, De Wet L (2015) Using a brain-computer interface (BCI) in reducing math anxiety: Evidence from South Africa. Comput Educ 81:113-122

11. Lécuyer A, Lotte F, Reilly RB, Leeb R, Hirose M, Slater M (2008) Brain-computer interfaces, virtual reality, and videogames. Computer 41(10):66-72

12. Nijholt ABCI (2008) for games: A 'state of the art' survey. International Conference on Entertainment Computing. Springer, pp 225-228

13. van de Laar B, Bos DP-O, Reuderink B, Poel M, Nijholt A (2013) How much control is enough? Influence of unreliable input on user experience. IEEE transactions on cybernetics 43(6):1584-1592

14. Sample M, Sattler S, Blain-Moraes S, Rodríguez-Arias D, Racine E (2019) Do publics share experts' concerns about brain-computer interfaces? A trinational survey on the ethics of neural technology. Science, Technology, \& Human Values 5(6):1242-1270
15. McCullagh P, Lightbody G, Zygierewicz J, Kernohan WG (2014) Ethical challenges associated with the development and deployment of brain computer interface technology. Neuroethics 7(2):109-122

16. Aas S, Wasserman D (2016) Brain-computer interfaces and disability: Extending embodiment, reducing stigma? J Med Ethics 42(1):37-40

17. Nijboer F, Clausen J, Allison BZ, Haselager P (2013) The Asilomar survey: Stakeholders' opinions on ethical issues related to brain-computer interfacing. Neuroethics 6(3):541-578

18. Grübler G, Al-Khodairy A, Leeb R, Pisotta I, Riccio A, Rohm M, Hildt E (2014) Psychosocial and ethical aspects in non-invasive EEG-based BCI research - a survey among BCI users and BCI professionals. Neuroethics 7(1):29-41

19. Ahn M, Lee M, Choi J, Jun S (2014) A review of brain-computer interface games and an opinion survey from researchers, developers and users. Sensors 14(8):14601-14633

20. Vansteensel MJ, Kristo G, Aarnoutse EJ, Ramsey NF (2017) The brain-computer interface researcher's questionnaire: From research to application. Brain-Computer Interfaces 4(4):236-247. https://doi.org/10.1080/2326263X. 2017.1366237

21. Pedrocchi A, Ferrante S, Ambrosini E, Gandolla M, Casellato C, Schauer T, Klauer C, Pascual J, Vidaurre C, Gföhler M (2013) MUNDUS project: Multimodal Neuroprosthesis for daily upper limb support. J Neuroeng Rehabil 10 (66)

22. Zickler C, Riccio A, Leotta F, Hillian-Tress S, Halder S, Holz E, Staiger-Sälzer P, Hoogerwerf E-J, Desideri L, Mattia D (2011) A brain-computer interface as input channel for a standard assistive technology software. Clin EEG Neurosci 42(4):236-244

23. Blain-Moraes S, Schaff R, Gruis KL, Huggins JE, Wren PA (2012) Barriers to and mediators of brain-computer interface user acceptance: Focus group findings. Ergonomics 55(5):516-525

24. Nijboer F, Plass-Oude Bos D, Blokland Y, van Wijk R, Farquhar J (2014) Design requirements and potential target users for brain-computer interfaces-recommendations from rehabilitation professionals. Brain-Computer Interfaces 1(1):50-61

25. Huggins JE, Wren PA, Gruis KL (2011) What would brain-computer interface users want? Opinions and priorities of potential users with amyotrophic lateral sclerosis. Amyotroph Lateral Scler 12(5):318-324. https://doi.org/ 10.3109/17482968.2011.572978

26. Huggins JE, Moinuddin AA, Chiodo AE, Wren PA (2015) What would brain-computer interface users want: Opinions and priorities of potential users with spinal cord injury. Arch Phys Med Rehabil 96(3):S38S45. e35

27. Peters B, Bieker G, Heckman SM, Huggins JE, Wolf C, Zeitlin D, Fried-Oken M (2015) Brain-computer interface users speak up: The Virtual Users' Forum at the 2013 International Brain-Computer Interface Meeting. Arch Phys Med Rehabil 96(3 Suppl):S33-S37. https://doi.org/ 10.1016/j.apmr.2014.03.037 
28. Vuckovic A, Osuagwu BA (2013) Using a motor imagery questionnaire to estimate the performance of a braincomputer interface based on object oriented motor imagery. Clin Neurophysiol 124(8):1586-1595

29. Kögel J, Schmid JR, Jox RJ, Friedrich O (2019) Using brain-computer interfaces: A scoping review of studies employing social research methods. BMC Medical Ethics $20(18)$

30. Schmid JR, Jox RJ (2021) The power of thoughts: A qualitative interview study with healthy users of braincomputer interfaces. In: Friedrich O, Wolkenstein A, Bublitz C, Jox RJ, Racine E (eds) Clinical neurotechnology meets artificial intelligence: Philosophical, ethical, legal and social implications. Springer International Publishing, Cham, pp 117-126. https://doi.org/10.1007/ 978-3-030-64590-8_9

31. Mayring P (2015) Qualitative Inhaltsanalyse. Grundlagen und Techniken. Beltz, Weinheim

32. Pluye P, Hong QN (2014) Combining the power of stories and the power of numbers: Mixed methods research and mixed studies reviews. Annu Rev Public Health 35:29-45. https://doi.org/10.1146/annurev-publhealth-032013-182440

33. Creswell JW (2014) A concise introduction to mixed methods research. SAGE publications, Los Angeles

34. Tashakkori A, Teddlie C (2009) Integrating qualitative and quantitative approaches to research. The SAGE handbook of applied social research methods 2:283-317

35. Döring N, Bortz J (2016) Forschungsmethoden und Evaluation. Springer, Berlin

36. Häder M (2010) Empirische Sozialforschung: Eine Einführung. Springer, Heidelberg

37. Karrer K, Glaser C, Clemens C, Bruder C (2009) Technikaffinität erfassen - der Fragebogen TA-EG. In: Lichtenstein A, Stößel C, Clemens C (eds) Der Mensch im Mittelpunkt technischer Systeme. VDI Verlag, Düsseldorf, pp 196-201

38. Bühner M (2011) Einführung in die Test-und Fragebogenkonstruktion. Pearson, München

39. Preston CC, Colman AM (2000) Optimal number of response categories in rating scales: Reliability, validity, discriminating power, and respondent preferences. Acta Physiol (Oxf) 104(1):1-15

40. FV V, Göritz AS, Sattler S (2016) Response effects of prenotification, prepaid cash, prepaid vouchers, and postpaid vouchers: An experimental comparison. Soc Sci Comput Rev 34(3):333-346

41. Göritz AS (2014) Determinants of the starting rate and the completion rate in online panel studies1. Online Panel Research: Data Quality Perspective, A:154-170

42. Hochberg LR, Anderson K (2012) BCI users and their needs. In: Wolpaw JR, Winter Wolpaw E (eds) Braincomputer interfaces. Principles and practice. Oxford University Press, New York, pp 317-324

43. Schicktanz S, Amelung T, Rieger JW (2015) Qualitative assessment of patients' attitudes and expectations toward BCIs and implications for future technology development. Frontiers in Systems Neuroscience 9 (64)

44. Gilbert F, Cook M, O'Brien T, Illes J (2019) Embodiment and estrangement: Results from a first-in-human "intelligent BCI” trial. Sci Eng Ethics 25(1):83-96
45. Yuste R, Goering S, Bi G, Carmena JM, Carter A, Fins JJ, Friesen P, Gallant J, Huggins JE, Illes J (2017) Four ethical priorities for neurotechnologies and AI. Nature News 551(7679): 159

46. OECD (2020) Recommendation of the Council on Responsible Innovation in Neurotechnology, OECD/ LEGAL/0457

47. Drew L (2019) The ethics of brain-computer interfaces. Nature 571:S19-S21. https://doi.org/10.1038/ d41586-019-02214-2

48. Hohensee M (2019) Das sind Elon Musks Cyborg-Pläne. Wirtschaftswoche https://www.wiwode/technologie/forschung/ neuralink-das-sind-elon-musks-cyborg-plaene/24669484html

49. Gilbert F, Pham C, Viaña J, Gillam W (2019) Increasing brain-computer interface media depictions: Pressing ethical concerns. Brain-Computer Interfaces 6(3):49-70

50. Müller O, Clausen J, Maio G (2009) Das technisierte Gehirn. Neurotechnologien als Herausforderung für Ethik und Anthropologie. Mentis, Paderborn

51. Schermer M (2009) The Mind and the machine. on the conceptual and moral implications of brain-machine interaction. NanoEthics 3(3):217-230. https://doi.org/10.1007/ s11569-009-0076-9

52. Kögel J, Wolbring G (2020) What it takes to be a pioneer: Ability expectations from brain-computer interface users. NanoEthics 14(3):227-239. https://doi.org/10.1007/ s11569-020-00378-0

53. Sahinol M (2016) Das techno-zerebrale Subjekt: Zur Symbiose von Mensch und Maschine in den Neurowissenschaften. transcript, Bielefeld

54. Reardon S (2017) AI-controlled brain implants for mood disorders tested in people. Nature News 551(7682):549

55. Steinert S, Bublitz C, Jox R, Friedrich O (2018) Doing things with thoughts: Brain-computer interfaces and disembodied agency. Philosophy \& Technology 32, pp 457-482

56. Bublitz C, Wolkenstein A, Jox RR, Friedrich O (2018) Legal liabilities of BCI-users: Responsibility gaps at the intersection of mind and machine? Int J Law Psychiatry 65, 101399

57. Müller S, Bittlinger $M$, Brukamp $K$, Christen $M$, Friedrich O, Gruber M-C, Leefmann J, Merkel G, Nagel SK, Stier M (2018) Neuroethik. Geschichte, Definition Gegenstandsbereich eines neuen Wissenschaftsgebiets. Ethik in der Medizin 30(2):91-106

58. Birbaumer N (2014) Dein Gehirn weiß mehr, als du denkst: Neueste Erkenntnisse aus der Hirnforschung. Ullstein eBooks, Hamburg

59. Eagleman D (2017) The Brain: Die Geschichte von dir. Pantheon, München

60. Harari YN (2017) Homo Deus: Eine Geschichte von Morgen. $\mathrm{CH}$ Beck, München

61. Burwell S, Sample M, Racine E (2017) Ethical aspects of brain computer interfaces: A scoping review. BMC Med Ethics 18(1):60

62. Clausen J, Fetz E, Donoghue J, Ushiba J, Spörhase U, Chandler J, Birbaumer N, Soekadar SR (2017) Help, hope, and hype: Ethical dimensions of neuroprosthetics. 
Science 356(6345):1338-1339. https://doi.org/10.1126/ science.aam 7731

63. Ahn S, Kim K, Jun SC (2016) Steady-state somatosensory evoked potential for brain-computer interface - present and future. Front Hum Neurosci 9(716):1-6

64. Allison BZ, Neuper C (2010) Could anyone use a BCI? In: Tan DS, Nieholt A (eds) Brain-computer interfaces. Applying our minds to human-computer interaction. Springer, London, pp 35-54

65. Guger C, Daban S, Sellers E, Holzner C, Krausz G, Carabalona R, Gramatica F, Edlinger G (2009) How many people are able to control a P300-based brain-computer interface (BCI)? Neurosci Lett 462(1):94-98
66. Thompson MC (2019) Critiquing the concept of BCI illiteracy. Sci Eng Ethics 25(4):1217-1233

67. Kellmeyer P, Cochrane T, Müller O, Mitchell C, Ball T, Fins JJ, Biller-Andorno N (2016) The effects of closedloop medical devices on the autonomy and accountability of persons and systems. Camb Q Healthc Ethics 25(4):623-633

68. Haselager P (2013) Did I do that? Brain-computer interfacing and the sense of agency. Mind Mach 23(3):405-418

Publisher's Note Springer Nature remains neutral with regard to jurisdictional claims in published maps and institutional affiliations. 